\title{
LONG-TERM DROUGHT VARIABILITY AND TRENDS IN BARCELONA (1787-2014)
}

\author{
J.R. COLL ${ }^{1 *}$, E. AGUILAR ${ }^{1}$, M. PROHOM ${ }^{2}$, J. SIGRÓ ${ }^{1}$ \\ ${ }^{1}$ Centre for Climate Change (C3), Geography Department, Universitat Rovira i Virgili, Spain. \\ ${ }^{2}$ Department of Climatology, Meteorological Service of Catalonia, Spain.
}

\begin{abstract}
Long-term drought variability and trends were assessed in Barcelona at annual and seasonal scale for the period 1787-2014 and sub-periods 1851-2014, 1901-2014 and 1951-2014 to identify changes in drought patterns across time. High quality and adjusted monthly temperature and precipitation series were required for this purpose. The Standardized Precipitation Index (SPI), based on precipitation, and the Standardized Precipitation Evapotranspiration Index (SPEI), based on the difference between precipitation and reference evapotranspiration (ETO), were calculated to describe temporal drought fluctuations. Therefore, major droughts and wet events were identified and an accurate analysis of drought severity, magnitude and duration were also carried out. Both drought indices provided similar results related to drought variability and trends in Barcelona across time, although the SPEI showed larger drought severity than SPI especially during the second half of the 20th century. Trends analysis revealed a significant drying trend at annual scale according to the SPEI since mid-19th century while the SPI did not show changes in drought patterns. At seasonal scale, both the SPI and SPEI found a clear drying trend only for summer (JJA) during the current period (1951-2014), although the SPEI was indicating the trend towards drier conditions for the whole period (1787-2014). Drought severity in SPEI series increased 13\% during the second half of the 20th century compared with the whole period under study while drought magnitude and duration did not present significant changes in both the SPI and SPEI series. The increasing atmospheric evaporative demand associated to the large temperature rising experienced in Barcelona during the last decades could have played a substantial role in explaining the increase of drought severity and trends found in the SPEI series.
\end{abstract}

\section{Variabilidad y tendencias a largo plazo de las sequías en Barcelona (1787-2014)}

RESUMEN. La variabilidad y las tendencias de las sequías han sido evaluadas para Barcelona a escala anual y estacional durante el período 1787-2014 y los subperíodos 1851-2014, 1901-2014 y 1951-2014 con el fin de identificar 
cambios en los patrones de sequía. Para este propósito se han usado datos mensuales de temperatura y precipitación de alta calidad y ajustados de Barcelona. La fluctuación de las sequías ha sido descrita a partir del cálculo del Índice de Precipitación Estandarizada (SPI), basado en la precipitación, y del Índice de Precipitación Evapotranspiración Estandarizada (SPEI), basado en la diferencia entre la precipitación y la evapotranspiración de referencia (ETO). Además, se han identificado las sequías extremas y los eventos húmedos extremos y se ha analizado cuidadosamente la evolución de la severidad, magnitud y duración de dichos eventos. Los dos índices de sequía utilizados en este estudio han arrojado resultados similares por lo que se refiere a variabilidad y tendencias en las sequías, pero el índice SPEI ha mostrado mayor severidad en las sequías que el SPI, especialmente durante la segunda mitad del siglo XX. El análisis de tendencias ha revelado una tendencia significativa hacia condiciones más secas a escala anual según el índice SPEI desde mediados del siglo XIX, mientras que el SPI no ha mostrado cambios en los patrones de sequía. A escala estacional, tanto el SPI como el SPEI han señalado una clara tendencia hacia condiciones más secas únicamente en verano (JJA) durante la segunda mitad del siglo XX (1951-2014), a pesar de que el SPEI ya había detectado dicha tendencia durante todo el período de estudio. La severidad de las sequías se ha incrementado un 13\% durante el período 1951-2014 comparado con el período 1787-2014, mientras que la magnitud y la duración de las sequías no han registrado cambios sustanciales en ambos índices de sequía. El incremento de la demanda de evaporación atmosférica asociada al aumento de la temperatura experimentado en Barcelona durante las últimas décadas podría haber jugado un papel destacado para explicar el incremento de la severidad de las sequías según las tendencias encontradas en las series del SPEI.

Key words: drought, Barcelona, SPI, SPEI, climate change.

Palabras clave: sequía, Barcelona, SPI, SPEI, cambio climático.

Received 28 December 2015 Accepted 2 February 2016

*Corresponding author: Centre for Climate Change (C3), Geography Department, Universitat Rovira i Virgili, Tortosa, Spain. E-mail: joanramon.coll@urv.cat

\section{Introduction}

Drought is a complex natural hazard characterized by prolonged abnormally dry conditions (Salomon et al., 2007) that can affect negatively the environment, population and human activities (Kallis, 2008). This extreme climate event constitutes common phenomena in the Iberian Peninsula. On the other hand, substantial changes in drought patterns were identified across the 20th century related to climate change (Coll, 2014, Hartmann et al., 2013; Vicente-Serrano et al., 2014a). A clear drying trend was found for most of the Iberian Peninsula with maximum rates of change in the south and south- 
western area, in the Ebro basin as well as in the Mediterranean coast especially for spring, but with largest drying trends for summer (Coll, 2014; Gallego et al., 2011; CLIVAR, 2010). At the same time, the population increase with the consequent growth of urban areas, industrial activity and the touristic development in the Mediterranean coastland areas during the last decades are increasing water demand for consumption and human activities. Then, drought severity is increasing not only due to climate change, but also related to the increase of water demand for life (Lorenzo-Lacruz et al., 2012).

Under this situation, it seems crucial to know how drought patterns are changing across time in the metropolitan urban areas, such as Barcelona, where precipitation decreased slightly since 1900 (Prohom et al., 2015), while a large temperature increase is found since the end of the 18th century, especially in summer (Prohom et al., 2012).

The main purpose of this study is to assess possible changes in long-term drought patterns in Barcelona at annual and seasonal scale since the end of the 18th century (1787-2014), but also using other sub-periods (1851-2014; 1901-2014 and 1951-2014). Two different drought indices (the SPI and SPEI) are used to perform drought variability and the magnitude of change is obtained by drought trends. Major droughts and wet events are identified since the end of the 18th century and the evolution of severity, duration and magnitude of the extreme events are accurately analysed to determine possible changes. The role of the reference evapotranspiration on drought severity is also assessed from drought variability and trends in order to establish a relationship between both parameters under climate change context.

\section{Data and methods}

\subsection{Observed data of Barcelona}

Monthly mean temperature and monthly precipitation were used to assess drought variability and trends in Barcelona for the period 1787-2014. As most long-term climatological time series are affected by multiple non climatic factors that do not allow to detect the climatic signal (Aguilar et al., 2003), quality control routines and homogenisation procedures had previously required to ensure consistency and statistical robustness to the final results. The quality control tests included in the RClimDexExtraQC software package (Aguilar and Prohom, 2010) and the HOMER homogenisation method (Mestre et al., 2013) have been applied to the monthly mean temperature (Prohom et al., 2012) and to the monthly precipitation (Prohom et al., 2015). The HOMER is a relative homogenisation method that integrates the best features from other existing methods becoming currently one of the best homogenisation method to adjust annual and monthly climate time series (Venema et al., 2012). The adjustment of the monthly climate series of Barcelona has ensured data consistency and reliability after the comparison with other observed and reconstructed climate series in the Western Mediterranean basin (Prohom et al., 2015).

Monthly maximum and minimum temperature and derived monthly mean temperature of Barcelona for the period 1901-2014 were also required to complete this study. The temperature data were obtained from last version of the Spanish Daily Temperature Series (SDATSv2) (Sigró et al., 2015). The SDATSv2 had 
subjected to quality control tests by using the RClimDexExtraQC software package (Aguilar and Prohom, 2010) and the Standard Normal Homogeneity test (SNHT) had also applied to monthly maximum and minimum temperatures. The SNHT (Alexandersson and Moberg, 1997) is based on the application of an iterative process using a candidate time series together with a group of reference time series. The iterative comparison between candidate and composite reference series allows the detection of inhomogeneities in the climate series. The SNHT methodology was used to adjust the newly SDATSv2 dataset to ensure data comparability with the first SDATS version (SDATSv1) (Brunet et al., 2006). The new approach to minimise the bias introduced in temperature series related to the replacement of open shelters by Stevenson screens, namely the screen bias (Brunet et al., 2011), had also included to the homogenisation process improving the final adjustment. The combination of both homogenisation procedures (the SNHT and the screen bias adjustment) had provided robust results related to the maximum and minimum temperature variability and change across Spain since the mid-19th century (Sigró et al., 2015).

\subsection{Drought indices}

The Standardized Precipitation Index (SPI) and the Standardized Precipitation Evapotranspiration Index (SPEI) were performed to describe drought variability in Barcelona for the period 1787-2014 according to drought categories (Table 1). The SPI (McKee et al., 1993) converts precipitation data to probabilities from long-term past records to transform them to standardized series (expressed in z-units) being able to quantify droughts at different time scales (Vicente-Serrano et al., 2014b). Nevertheless, its calculation is based only on precipitation data knowing that other relevant variables as temperature, solar radiation, wind speed or relative humidity among others can undertake a remarkable role in drought development (Sheffield et al., 2012). The SPEI (Vicente-Serrano et al., 2010a) is based on the original SPI calculation procedure, but the reference evapotranspiration (ET0) is included in the algorithm together with precipitation and can also be calculated at different time scales. The use of the SPEI is particularly appropriate when quantifying droughts under global warming due to the changes produced in the ET0 during the last decades will be reported to the SPEI series (Vicente-Serrano et al., 2014a).

Table 1. Drought classification according to the SPI and SPEI categories based on McKee et al. (1993).

\begin{tabular}{|l|l|}
\hline \multicolumn{1}{|c|}{ CATEGORIES } & \multicolumn{1}{c|}{ z-units } \\
\hline Extremely wet & $\geq+2$ \\
\hline Severely wet & $\geq+1.5$ to $<+2$ \\
\hline Moderately wet & $\geq+1$ to $<+1.5$ \\
\hline Near normal & $>-1$ to $<+1$ \\
\hline Moderately dry & $>-1.5$ to $\leq-1$ \\
\hline Severely dry & $>-2$ to $\leq-1.5$ \\
\hline Extremely dry & $\leq-2$ \\
\hline
\end{tabular}


The ET0 can be estimated by using different methods such as PenmanMonteith, Hargreaves or Thornthwaite, among others. But the use of one or another ET0 estimation method strongly depends on the long-term data quality and availability. For this reason, one of the more physically realistic ET0 estimation method such Penman-Monteith could not be applied in this study due to no long and high quality series of observed wind speed, relative humidity, solar radiation and cloud cover were available even during the last 30 years of records. According to the data availability for Barcelona (long-term monthly maximum, minimum and mean temperature and monthly precipitation), the Hargreaves equation (first) and the Thornthwaite equation (second) are the most suitable methods to compute ET0 respectively (Beguería et al., 2014) after accepting the Penman-Monteith formulation as unfeasible option for this study. The Thornthwaite's method (Thornthwaite, 1948) only requires mean monthly temperature and solar radiation (estimated as a function of temperature and geographical coordinates) to be calculated, while the Hargreaves method (Hargreaves and Samani, 1985) needs maximum and minimum temperature and the extraterrestrial solar radiation (which depends on the latitude and the day of the year) to be computed.

In this study, the SPI and the SPEI based on the Thornthwaite equation (SPEITh) were performed for Barcelona by computing the 3-, 6-, 12-, and 24-month time scales for the period 1787-2014 in order to identify changes in meteorological droughts (3-month), agricultural droughts (6-months) and hydrological droughts (12- and 24-months). Nevertheless, the annual (12 months) SPEI based on the Hargreaves equation (SPEIHg) and the SPEITh were also calculated for the common period 19012014 to make comparisons between both ET0 estimation approaches. Root Mean Squared Error (RMSE), Pearson's r coefficient and linear trend and its significance were the statistics applied to quantify the differences between both ET0 estimation methods. The log-logistic probability distribution and the unbiased probability weighted moments were applied to the SPI and SPEI calculation to achieve accurate SPI and SPEI series following the recommendations given by Beguería et al. (2014). The calibration period (reference period required to estimate the main parameters of the SPI and SPEI algorithms) was the longest period available for all computations to avoid the exclusion of some major dry or wet periods, which could affect negatively the magnitude of drought trends (Trenberth et al., 2014).

\subsection{Definition of droughts and wet events}

Droughts and wet events can be defined as the time period in which a determined number of consecutive months reach a specific threshold level from the SPI and SPEI drought time series. For this study, the threshold level was applied to the annual (12 month) SPI and SPEI and it was established at 20\% (Percentile 20, P20) of the cumulative probability for droughts (SPI or SPEI <-0.8 z-units) and at $80 \%$ (Percentile 80, P80) for wet events (SPI or SPEI $>0.8$ z-units) following the approach described in Vicente-Serrano et al. (2014b). Then, a drought event (or wet event) was identified when the monthly 12 -month SPI or SPEI reached -0.8 z-units 
(or $0.8 \mathrm{z}$-units) from the SPI and SPEI time series. Once droughts and wet events were identified, maximum and average severity, duration and magnitude of each event were derived across time. Maximum (or average) severity is referred to the maximum (or average) monthly SPI or SPEI value recorded for each drought or wet event. The duration is taken as the number of consecutive months (one or more months) where the SPI or SPEI remains $<$ P20 for droughts or $>$ P80 for wet events. The magnitude is estimated as the sum of the SPI or SPEI index values recorded during the duration of each event. After the SPI and SPEI computation, series of maximum and average severity, duration and magnitude of droughts and wet events were performed for Barcelona during the whole period (1787-2014).

\subsection{Trends calculation}

The evolution of annual (12 month) and seasonal (3 month) SPI and SPEI time series for Barcelona was assessed by computing trends for the whole period 1787-2014 and also for different sub-periods; 1851-2014, 1901-2014 and 1951-2014 in order to identify changes in drought patterns across time. More than 60-year sub-periods were established to achieve reliable drought trends taking into account the cyclic drought occurrence (Santos et al., 2010). The sub-period 1851-2014 was chosen in order to figure out changes in drought trends when removing major dry conditions occurred in the early 19th century (Prohom et al., 2015) while the subperiod 1901-2014 was of interest to assess drought trends across the 20th century. Finally, trends computed from the sub-period 1951-2014 informed us about changes in drought patterns during the period of maximum temperature increase related to climate change (Salomon et al., 2007). Trends of maximum and average severity, duration and magnitude of droughts and wet events were also calculated based on the same sub-periods mentioned above. We used the Sen Slope estimator (Sen, 1969) introduced to climate analysis by Wang and Swail (2001) to assess the magnitude of linear trends in our time series and the nonparametric Mann-Kendall test (Kendall, 1970) to evaluate their significance. The Mann-Kendall test is a more robust statistical technique than equivalent parametric tests to estimate the trends significance. The statistical significance of trends was established at the $95 \%(\mathrm{p}<0.05)$.

\section{Results}

\subsection{Comparison between the SPEI series based on the Thornthwaite and Hargreaves ETO equations}

The SPEI series based on the Thornthwaite equation (SPEITh) and Hargreaves equation (SPEIHg) were compared for the common period 1901-2014 to assess the effect of using different ET0 equations on the SPEI drought index in Barcelona at annual scale. The Pearson's r coefficient, the RMSE and the linear trend and its statistical significance were computed to analyse the differences between the SPEITh and SPEIHg. Figure 1 shows drought evolution in Barcelona according to the annual SPEITh, the SPEIHg and the difference (Hg-Th) for the period 1901-2014. No large differences were found 
between the annual SPEITh and SPEIHg. Despite this, drought severity was larger during the last three decades of the time series (1990s, 2000s and 2010s) according to the SPEIHg estimate than the SPEITh, but the opposite situation occurred in the 1970s and 1980s. The correlation between the SPEIHg and SPEITh was significantly high (Pearson's $\mathrm{r}$ coefficient $=0.97 ; \mathrm{p}<0.01$ ) and the difference performed by the RMSE resulted in $0.23 \mathrm{z}$-units. The magnitude of change assessed from the trend calculation showed a significant decreasing trend $(\mathrm{p}<0.05)$ in both methods for the period 19012014, although slightly larger drought severity was found by using the SPEITh $(-0.0069$ z-units decade-1) than the SPEIHg (-0.0064 z-units decade-1). The results confirmed that both ET0 estimation methods included in the SPEI drought index provided similar results in Barcelona for the period 1901-2014 in terms of drought variability and trends. For this reason, the ET0 was computed by using the Thornthwaite equation to assess drought variability and change through SPEITh in Barcelona for the period 17872014. The lack of maximum and minimum temperature records availability made the Hargreaves formulation unfeasible to compute the SPEIHg during late 18th century and 19 th century in Barcelona.

\subsection{Description of drought variability by using SPI and SPEI}

Variability of drought and wet conditions was assessed from the 3-, 6-, 12- and 24-month SPI (Fig. 2) and SPEITh series (Fig. 3) obtained from the monthly mean temperature and monthly accumulated precipitation series of Barcelona for the period 1787-2014. Fluctuations in drought and wet conditions were similar in all time scales during the whole period, but temporal frequency of the SPI and SPEITh series was larger in short time scales than in long time scales due to the cumulative character of both indices. In general, the evolution of the SPI and SPEITh series showed similar drought variability across time indicating wet conditions in the 1800s, 1840s, 1850s, 1870s, 1900s, 1910s, 1960s and 1970s while drought conditions dominated especially in the 1810s, 1820s 1830s, 1860s, 1880s, 1920s, and 1950s. The severity of drought and wet conditions was larger in the SPI than in the SPEITh series during almost the whole period under study, but the SPEITh showed larger severity in drought episodes than SPI in the last 30-year period of the time series (1980s, 1990s and 2000s) for all time scales. In particular, drought conditions occurred from 1997 to 2009 were larger in the SPEITh than in the SPI series. Nevertheless, both indices coincided to identify major drought conditions in average from 1812 to 1838 in Barcelona while major wet conditions occurred from 1971 to 1973 . The period 1812-1838 was exceptionally dry due to a strong decrease in precipitation at annual and seasonal scale. For instance, more than $80 \%$ of annual precipitation was below the climatological mean for the period 1806-1841 (Prohom et al., 2015). This means that Barcelona was more than two decades under dry conditions with a few drought interruptions. Extremely dry conditions were also found in southern Europe for the period 1808-1835 according to Pauling et al. (2006). The main cause of this extremely dry period was the large decrease of precipitation due to the high volcanic activity during the solar Dalton Minimum in the early 19th century (Anet et al., 2014; Domínguez-Castro et al., 2012). 

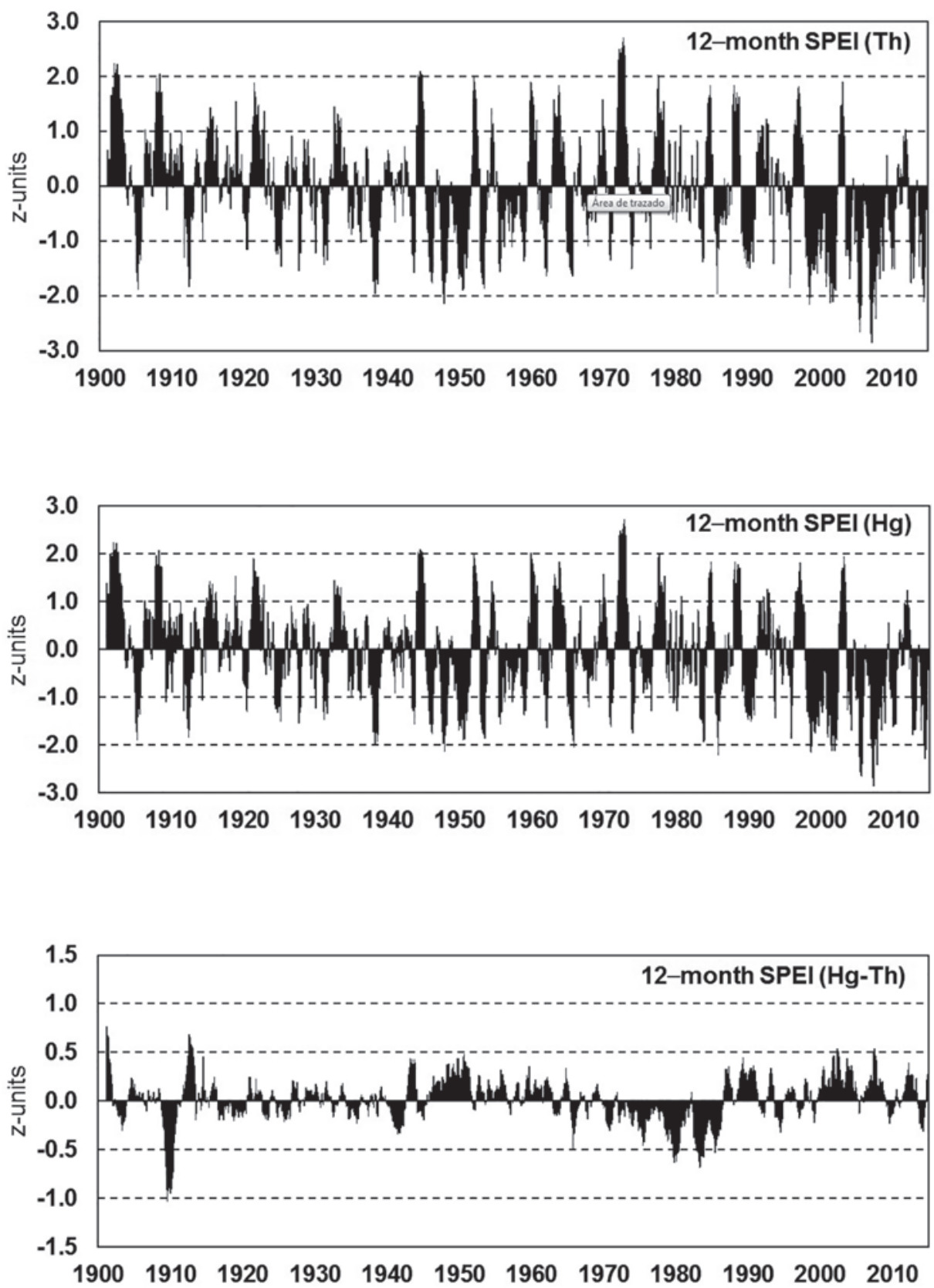

Figure 1. 12-month SPEI time series for Barcelona (1901-2014) based on the Thornthwaite (Th) and Hargreaves $(\mathrm{Hg})$ reference evapotranspiration equations and differences between both ETO estimation methods $(\mathrm{Hg}-\mathrm{Th})$. 

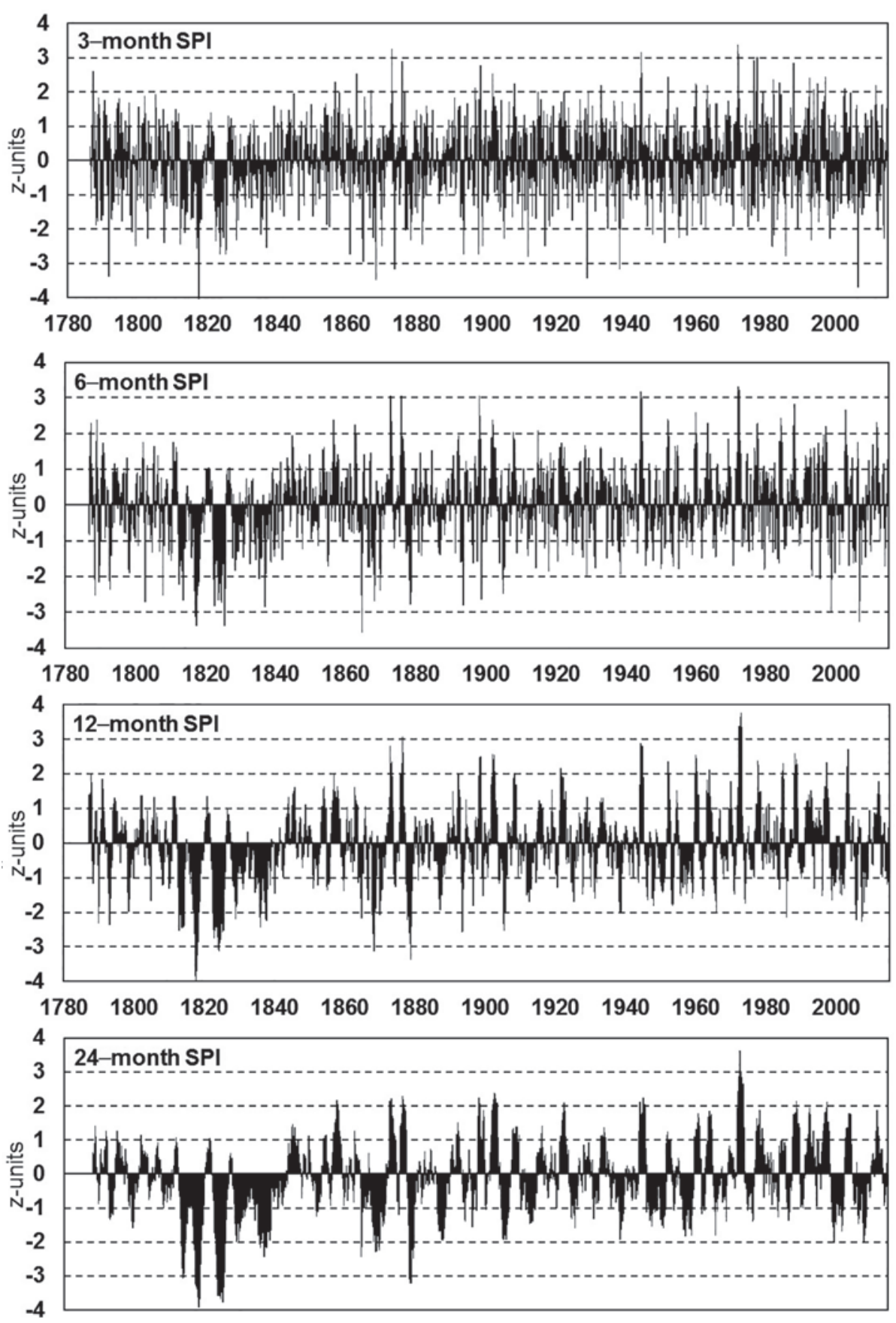

Figure 2. Drought variability from the 3-, 6-, 12- and 24-month SPI computed for Barcelona (1787-2014). 

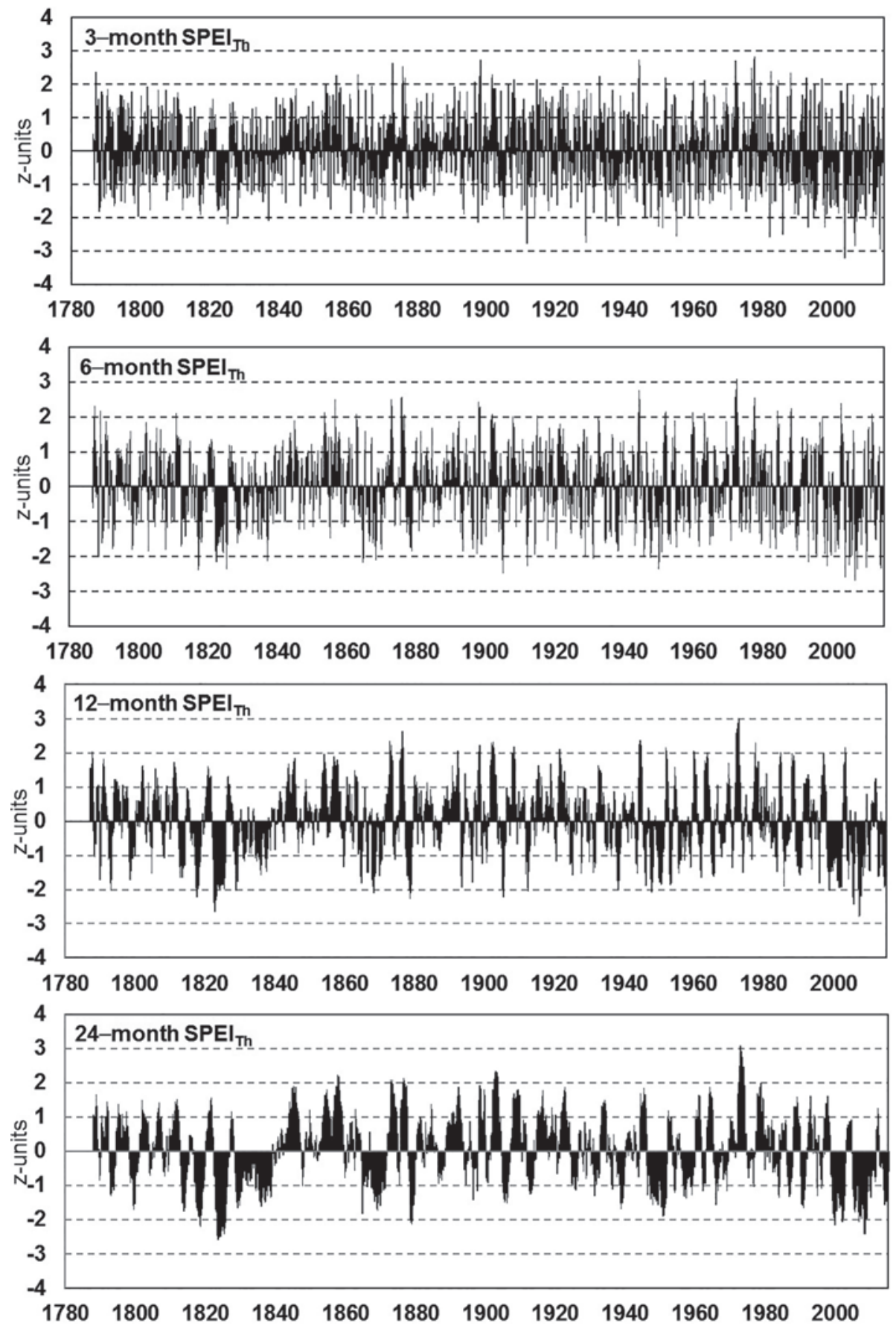

Figure 3. Drought variability from the 3-, 6-, 12- and 24-month SPEITh computed for Barcelona (1787-2014). 


\subsection{Identification of drought and wet events}

Droughts and wet events were identified in Barcelona for the period 1787-2014 from the annual (12 months) SPI and SPEITh series (Fig. 4) according to the threshold level $(<\mathrm{P} 20$ for droughts or $>\mathrm{P} 80$ for wet events) described in section 2.3. Major droughts and wet events identified according to the magnitude reached for each event, and the duration in months were listed in table 2. Both the SPI and the SPEITh series agreed to identify the major drought occurred in Barcelona between the years 1822 and 1825. This exceptional drought lasted more than 40 consecutive months reaching the maximum severity between 1823 and 1824, when extremely dry conditions (Table 1) dominated during 12 consecutive months. Moreover, both indices were also able to identify the wettest event in Barcelona to years 1971 and 1972 (also including 1973 only in the SPEITh series). This major wet event lasted more than 15 consecutive months reaching extremely wet conditions during 12 consecutive months. Other major droughts were identified by the SPI exclusively in the early 19th century coinciding with the driest period already described in section 3.2, but the SPEITh also found one major drought in late 20th century and one more in early 21 st century according to the top five droughts listed in table 2. It is worth mentioning that the second major drought of the time series identified by the SPEITh occurred between 2006 and 2008, when extremely dry conditions prolonged during seven consecutive months. The precipitation deficit was the worst since the mid-1940s (Pastor, 2008) and the reservoirs supplying Barcelona had fallen to 20\% of their capacity in March of 2008. Emergency actions such as transporting water to the city by sea tankers or building pipes to distant rivers had to put on the table. Therefore, awareness campaigns aiming to voluntary reductions in water consumption had also launched (March et al., 2013).

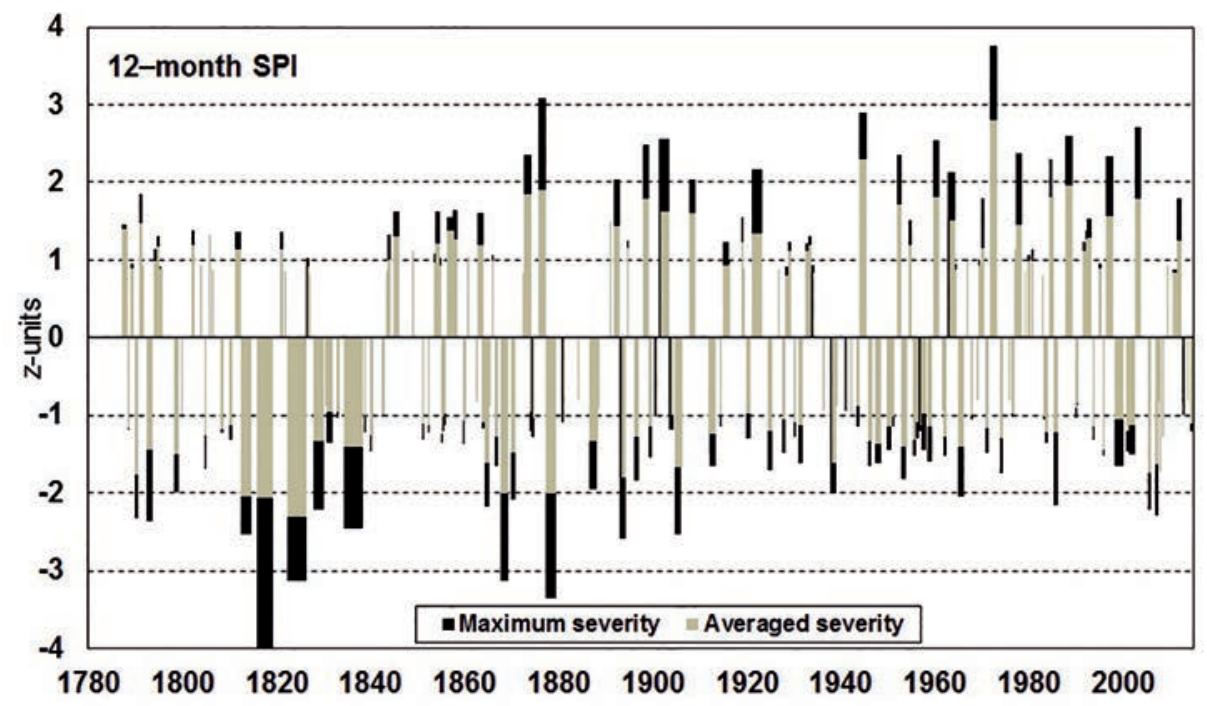




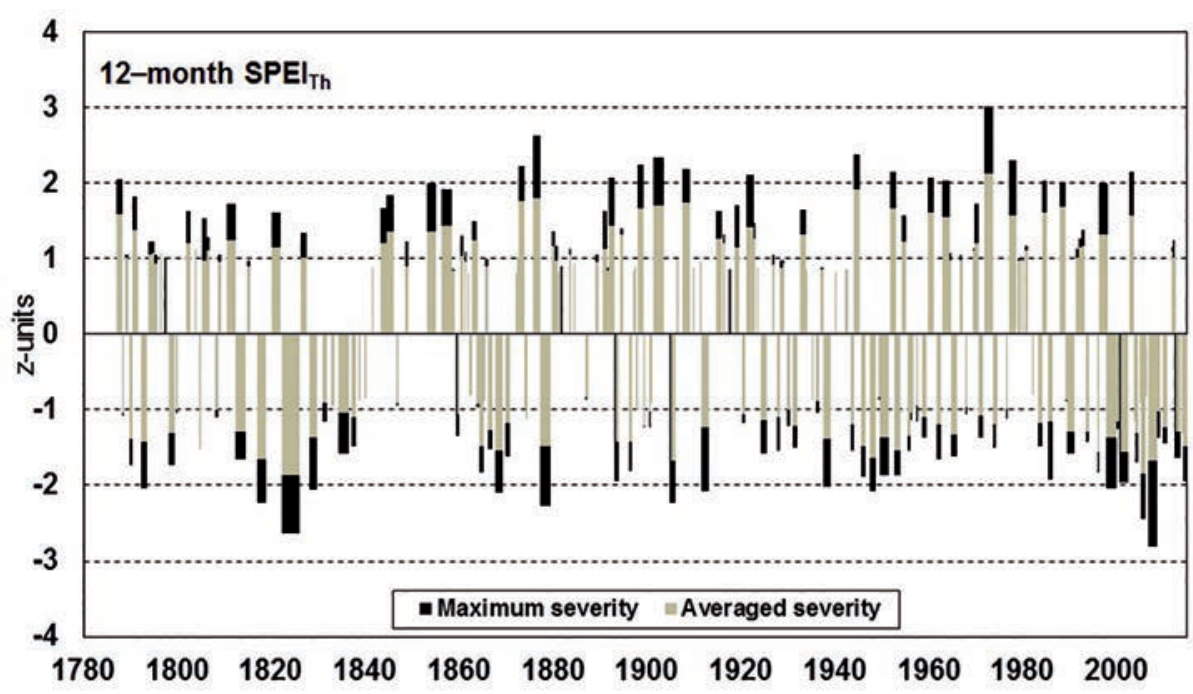

Figure 4. Droughts and wet events identified for Barcelona (1787-2014) by using the 12-month SPI and SPEITh series. Black bars (or grey bars) are referred to the maximum severity (or average severity) reached for each drought and wet event and bars width's are proportional to duration in months.

Table 2. Major droughts and wet events identified in Barcelona (1787-2014) according to the magnitude (in z-units) reached for each event by using the 12-month SPI and SPEITh series. The period and the duration in months are also shown.

\begin{tabular}{|c|c|c|c|c|c|c|}
\hline & \multicolumn{3}{|c|}{ 12-month SPI } & \multicolumn{3}{|c|}{ 12-month SPEITh } \\
\hline & Period & Magnitude & Duration & Period & Magnitude & Duration \\
\hline \multirow{5}{*}{ 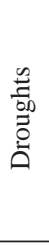 } & $1822-1825$ & 103.4 & 45 & $1822-1825$ & 79.8 & 43 \\
\hline & $1815-1818$ & 80.3 & 39 & 2006-2008 & 33.7 & 20 \\
\hline & $1834-1837$ & 64.7 & 46 & $1817-1818$ & 33.1 & 20 \\
\hline & $1812-1814$ & 47.0 & 23 & $1877-1878$ & 32.8 & 22 \\
\hline & $1877-1878$ & 44.2 & 22 & 1997-1999 & 31.2 & 23 \\
\hline \multirow{5}{*}{$\begin{array}{l}0 \\
\stackrel{0}{0} \\
\overrightarrow{0} \\
\stackrel{0}{0} \\
\dot{3}\end{array}$} & 1971-1972 & 44.9 & 16 & 1971-1973 & 42.8 & 20 \\
\hline & 1901-1902 & 35.3 & 22 & 1901-1903 & 37.6 & 22 \\
\hline & 1943-1944 & 32.1 & 14 & $1856-1858$ & 35.9 & 25 \\
\hline & $1875-1876$ & 30.4 & 16 & $1875-1876$ & 29.0 & 16 \\
\hline & $1921-1922$ & 28.2 & 21 & $1943-1944$ & 26.8 & 14 \\
\hline
\end{tabular}

Figure 5 shows the distribution of the identified droughts and wet events in Barcelona for the whole period under study according to the magnitude reached for each event related with the duration in months by using the annual SPI and SPEITh series. Obviously, most of droughts and wet events remained in low magnitude and duration 
due to high variability between wet and dry months that did not allow to produce dry or wet conditions for a long time, but this was not so in the few cases described in table 2 as major droughts and wet events. The accumulative character of droughts and wet events was identified by noting that when the duration for a given event increased so did the magnitude establishing a strong relationship between both parameters (Pearson's $r$ coefficient $=0.97$ statistically significant at the $95 \%$ level; $\mathrm{p}<0.01$ ). This is obvious due to the duration in time for a given event implied more or less accumulated severity, so more or less magnitude recorded in droughts and wet events.
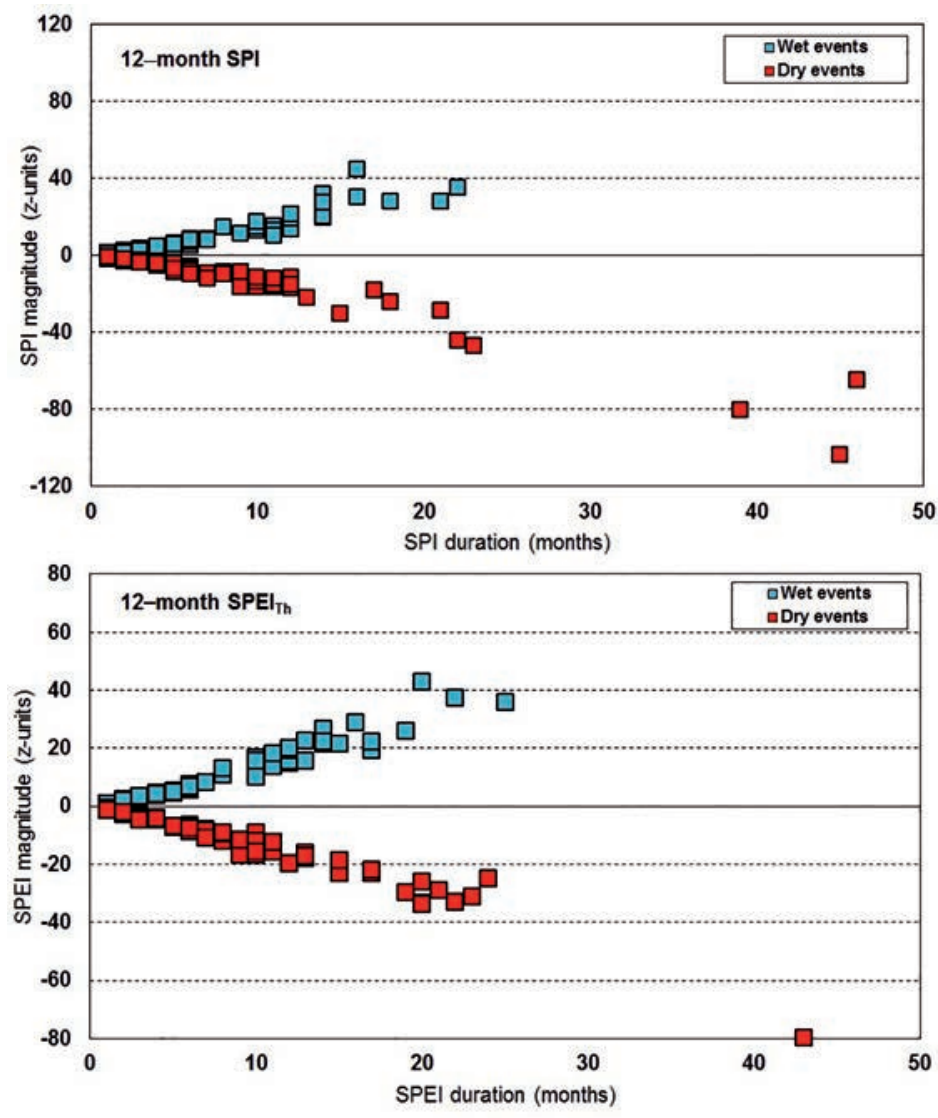

Figure 5. Behaviour of identified droughts and wet events in Barcelona (1787-2014) according to the magnitude reached for each event related with the duration in months by using 12-month SPI and SPEITh series.

\subsection{Drought trends}

Drought trends in the annual and seasonal SPI and SPEITh series for the whole period 1787-2014 and sub-periods 1851-2014, 1901-2014 and 1951-2014 were assessed 
to find changes in drought patterns for Barcelona across time. The magnitude of change in annual (12 months) and seasonal (3 months) SPI and SPEITh series is shown in table 3. The SPI and SPEITh did not show a clear change in drought patterns at annual scale for the whole period under study $(1787-2014)$, but a significant drying trend $(\mathrm{p}<0.05)$ was found only by the SPEI for the sub-periods 1851-2014, 1901-2014 and 1951-2014 increasing progressively the magnitude of change towards drier conditions across time.

Table 3. Magnitude of change (in z-units decade-1) in the annual (12 months) and seasonal (3 months) SPI and SPEITh series for the whole period 1787-2014 and sub-periods 1851-2014, 1901-2014 and 1951-2014. Marked values (*) are referred to statistical significant trends at the $95 \%$ level $(p<0.05)$.

\begin{tabular}{|l|c|c|c|c|c|c|c|c|}
\cline { 2 - 9 } \multicolumn{1}{c|}{} & \multicolumn{4}{c|}{ SPI } & \multicolumn{4}{c|}{ SPEITh } \\
\cline { 2 - 9 } \multicolumn{1}{c|}{} & $\mathbf{1 7 8 7 - 2 0 1 4}$ & $\mathbf{1 8 5 1 - 2 0 1 4}$ & $\mathbf{1 9 0 1 - 2 0 1 4}$ & $\mathbf{1 9 5 1 - 2 0 1 4}$ & $\mathbf{1 7 8 7 - 2 0 1 4}$ & $\mathbf{1 8 5 1 - 2 0 1 4}$ & $\mathbf{1 9 0 1 - 2 0 1 4}$ & $\mathbf{1 9 5 1 - 2 0 1 4}$ \\
\hline Annual & 0.015 & 0.003 & 0.005 & 0.002 & -0.012 & $-0.045^{*}$ & $-0.079^{*}$ & $-0.158^{*}$ \\
\hline DJF & $0.024^{*}$ & 0.014 & 0.007 & 0.033 & 0.017 & 0.006 & -0.004 & 0.020 \\
\hline MAM & 0.017 & 0.011 & -0.006 & 0.051 & 0 & -0.013 & -0.039 & -0.015 \\
\hline JJA & 0.017 & -0.001 & -0.023 & $-0.182^{*}$ & $-0.027^{*}$ & $-0.057^{*}$ & $-0.095^{*}$ & $-0.338^{*}$ \\
\hline SON & 0 & -0.019 & 0.010 & 0.028 & -0.013 & -0.037 & -0.019 & -0.031 \\
\hline
\end{tabular}

At seasonal scale, a wetting trend was identified by both the SPI and SPEITh for winter (DJF) in all sub-periods being statistically significant only in the SPI for the period 1787-2014. No significant trends were found in spring (MAM) according to the results provided by the SPI and SPEITh series. The SPI detected a wetting trend since the second half of the 20th century in spring, meanwhile the SPEITh identified a slightly drying trend along the 20th century, but in all cases the magnitude of change was statistically non-significant. Nevertheless, a statistically significant drying trend was found in summer (JJA) according to the SPEITh for the whole periods and sub-periods, but becoming only significant in the SPI during the second half of the 20th century. A slightly wetter trend was encountered in autumn (SON) by the SPI especially during the second half of the 20th century, although the SPEITh showed a drying trend for all subperiods, but statistically non-significant in all cases.

Trends in the maximum severity, average severity, magnitude and duration of droughts and wet events according to the annual SPI and SPEITh for the whole period and sub-periods are shown in table 4. Most of the parameters mentioned above showed a no clear change in drought patterns according to the annual SPI for all sub-periods. However, only the maximum and average severity of droughts experienced a significant increase $(\mathrm{p}<0.05)$ in the annual SPEITh for the second half of the 20th century. This means that maximum severity and average severity of droughts increased a $13 \%$ and $11 \%$ respectively in Barcelona for the period 1951-2014 compared with the 1787-2014 base-period. No clear change in parameters related to wet events was found in both the annual SPI and SPEITh series. 
Table 4. Magnitude of change (in z-units-months decade-1) in the maximum severity, average severity, magnitude and duration of droughts and wet events according to 12-month SPI and SPEITh series for the whole period 1787-2014 and sub-periods 1851-2014, 1901-2014 and 1951-2014. Marked values (*) are referred to statistical significant trends at the $95 \%$ level $(p<0.05)$.

\begin{tabular}{|c|c|c|c|c|c|c|c|c|c|}
\hline & \multicolumn{4}{|c|}{ Droughts } & \multicolumn{4}{|c|}{ Wet events } \\
\hline & & $1787-2014$ & $1851-2014$ & 1901-2014 & 1951-2014 & $1787-2014$ & $1851-2014$ & 1901-2014 & 1951-2014 \\
\hline \multirow{4}{*}{ 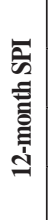 } & Max. Sev. & -0.023 & -0.012 & -0.027 & -0.052 & 0.032 & -0.021 & -0.012 & -0.129 \\
\hline & Avg. Sev. & -0.012 & -0.004 & -0.003 & -0.014 & 0.013 & -0.015 & -0.011 & -0.074 \\
\hline & Magnitude & -0.149 & -0.076 & -0.369 & -0.820 & 0.216 & -0.014 & -0.290 & -0.700 \\
\hline & Duration & 0 & 0 & -0.370 & -0.769 & 0 & 0 & 0 & 0 \\
\hline \multirow{4}{*}{ 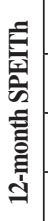 } & Max. Sev. & 0.015 & 0.034 & -0.010 & $0.073^{*}$ & 0.014 & 0.037 & 0.060 & -0.025 \\
\hline & Avg. Sev. & 0.013 & 0.027 & 0.027 & $0.067^{*}$ & 0.012 & 0.026 & 0.035 & -0.043 \\
\hline & Magnitude & 0.044 & 0.277 & -0.287 & 0.132 & 0.040 & 0.210 & 0.474 & -0.300 \\
\hline & Duration & 0 & 0.179 & -0.286 & 0 & 0 & 0 & 0.385 & 0 \\
\hline
\end{tabular}

\section{Discussion and conclusions}

This study analyses long-term drought variability and trends in Barcelona at annual and seasonal scale over more than 225 years extending from the end of the 18th century till 2014. The SPI and SPEI were used to identify droughts and wet events for the period 1787-2014 and the drought severity, magnitude and duration were quantified for each event.

The SPI is only based on precipitation variability and the SPEI estimates the difference between precipitation and ET0. Most of the studies recommended the use of Penman-Monteith model to compute ET0 (Dai, 2011; van der Schrier et al., 2011 among others), but unfortunately it could not be applied in this study due to the lack of long-term data availability. Therefore, two different ET0 approaches (Thornthwaite and Hargreaves equations) were tested and compared to assess the effect of both ET0 equations on the SPEI drought index. The results confirmed that both ET0 estimation methods provided similar results in Barcelona in terms of drought variability and trends. These results are consistent with Vicente-Serrano et al. (2014a), Dai (2011, 2012) and van der Schrier et al. (2013) who determined that the increasing drought severity experienced during the last decades was not related to the usage of different ET0 estimation methods. Despite this, Sheffield et al. (2012) found substantial differences in long-term drought trends by testing various ET0 models at global scale. According to the evident similarities found in both the SPEITh and SPEIHg series in this study, the SPI and SPEI based on the Thornthwaite equation (SPEITh) were selected for the drought analysis in Barcelona during the period 1787-2014 due to the unfeasibility of the SPEIHg to cover the whole period. In this line, drought trends should be treated carefully taking into account that the equation used to 
calculate ET0 could potentially influence long-term trends in the SPEI series due to its simplicity compared to other more physically realistic ET0 estimation methods.

The results obtained from the comparison of the SPI and SPEITh series concluded that both indices provided similar drought variability in Barcelona, but the SPEITh showed larger severity in drought episodes than SPI during the last 30-year period of the time series. Both indices also agreed to identify the major drought occurred in Barcelona between years 1822 and 1825 and the wettest event to years 1971 and 1972 . This is in good agreement with Prohom et al. (2015) who listed the years 1822, 1823 and 1824 into the top six of the driest years in Barcelona (1787-2014) during the exceptional dry period occurred in the early 19th century (Domínguez-Castro et al., 2012), while the wettest year of the time series was also 1971. From the similarities found in both the SPI and SPEITh series can be concluded that precipitation is the main driver on drought variability according to drought indices, but reference evapotranspiration (only included in the SPEITh) is playing a substantial role in explaining drought severity especially during the last three decades. Drought severity is increasing due to greater evaporative demand by the atmosphere strongly related to temperature rise only reported in SPEI series (Vicente-Serrano et al., 2014a). For instance, only the SPEITh was able to identify the second major drought of the time series occurred between 2006 and 2008 in Barcelona. The reservoirs supplying the city had fallen to the $20 \%$ of their capacity and the gravity of the situation forced the authorities to ban some water uses such as public fountains and watering private gardens, even the use of water for swimming pools was prohibited. Economic costs of the adopted emergency measures during the drought reached 490 million Euro and new water supply solutions were thoroughly discussed till June of 2008, when a very wet event left reservoirs at $80-90 \%$ of their capacity (March et al., 2013).

Trends analysis showed a clear drying trend at annual scale and also for summer (JJA) according to the SPEITh reaching the largest magnitude of change during the second half of the 20th century. Drying trends were larger in the SPEITh than SPI, especially for summer (JJA), mainly caused by the increasing atmospheric evaporative demand associated to the large temperature rising experienced in Barcelona $\left(+0.47^{\circ} \mathrm{C}\right.$ decade) for the period 1961-2011 (Prohom et al., 2012). Nevertheless, both the SPI and SPEITh also agreed to identify a wetting trend for winter (DJF) being statistically significant only in the SPI for the period 1787-2014. The maximum and average severity of droughts showed a significant increase of $13 \%$ and $11 \%$ respectively in the annual SPEITh for the second half of the 20th century. No clear change in parameters related to wet events was found in both the annual SPI and SPEITh series. Sousa et al. (2011), Vicente-Serrano et al. (2011) and Lorenzo-Lacruz et al. (2012) also found a drying trend across the Iberian Peninsula for the second half of the 20th century and Sheffield et al. (2012) and van der Schrier et al. (2013) also reported drier conditions over the whole Mediterranean basin. The results are in good agreement with annual precipitation trends observed in the Iberian Peninsula, which presented high inter-annual variability but did not show appreciable changes across the 20th century (Coll, 2014; Bladé et al., 2010). Nevertheless, a decrease in seasonal and annual precipitation was also identified in the 
Mediterranean area of the Iberian Peninsula for the second half of the 20th century (de Luis et al., 2009; Rodríguez-Puebla et al., 2010).

Future drought projections are pointing toward drier conditions in the Mediterranean basin across the 21st century (Kirtman et al., 2013) also including the Mediterranean coast of the Iberian Peninsula (Coll et al., 2015).

\section{Acknowledgements}

This work is supported by the project "Determinación y ajuste del sesgo introducido por la automatización de las estaciones meteorológicas en las series climáticas: CGL201232193", and it has been possible thanks to the project "CAFIDEXPI CGL2007-65546C03-02-CLI". Monthly mean temperature and precipitation of Barcelona were obtained from the Meteorological Service of Catalonia (SMC), while monthly maximum and minimum temperature were provided by AEMET. The SPEI package (available at: https://cran.r-project.org/web/packages/SPEI/index.html) was used to compute both the SPI and SPEI indices.

\section{References}

Aguilar, E., Auer, I., Brunet, M., Peterson, T.C., Wieringa, J. 2003. Guidelines on climate metadata and homogenization. World Meteorological Organization, Geneva, $51 \mathrm{pp}$.

Aguilar, E., Prohom, M. 2010. ExtraQC Quality Control Software. Available at: http://www. c3.urv.cat/data.html.

Alexandersson, H., Moberg, A. 1997. Homogenisation of Swedish temperature data, Part I: Homogeneity test for linear trends. International Journal of Climatology 17, 25-34.

Anet, J.G., Muthers, S., Rozanov, E.V., Raible, C.C., Stenke, A., Shapiro, A.I., Brönnimann, S., Arfeuille, F., Brugnara, Y., Beer, J., Steinhilber, F., Schmutz, W., Peter, T. 2014. Impact of solar versus volcanic activity variations on tropospheric temperatures and precipitation during the Dalton Minimum. Climate of the Past 10 (3), 921-938. Doi: 10.5194/cp-10-9212014.

Beguería, S., Vicente-Serrano, S.M., Reig, F., Latorre, B. 2014. Standardized precipitation evapotranspiration index (SPEI) revisited: parameter fitting, evapotranspiration models, tools, datasets and drought monitoring. International Journal of Climatology 34, 30013023. Doi: $10.1002 /$ joc.3887.

Bladé, I., Cacho, I., Castro-Díez, Y., Gomis, D., González-Sampériz, P., Míguez-Macho, G., Pérez Fiz, F., Rodríguez-Fonseca, B., Rodríguez-Puebla, C., Sánchez, E., Sotillo Marcos, G., Valero-Garcés, B., Vargas-Yáñez, M. 2010. Informe CLIVAR. Clima en España: Pasado, presente y futuro. In F. Pérez, R. Boscolo (eds.), http://www.aeclim.org/images/stories/ articulos_pdf/informe_clivar_2010.pdf.

Brunet, M., Asin, J., Sigró, J., Bañón, M., García, F., Aguilar, E., Palenzuela, J.E., Peterson, T.C., Jones, P. 2011. The minimisation of the screen bias from ancient Western Mediterranean air temperature records: an exploratory statistical analysis. International Journal of Climatology 31, 1879-1895. Doi: 10.1002/joc.2192.

Brunet, M., Saladié, O., Jones, P.D., Sigró, J., Aguilar, E., Moberg, A., Walther, A., Lister, D., López, D., Almarza, D. 2006. The development of a new daily adjusted temperature dataset for Spain (1850-2003). International Journal of Climatology 26, 1777-1802. 
Coll, J.R. 2014. Drought variability and change across the Iberian Peninsula. PhD dissertation, Rovira i Virgili University www.tdx.cat/bitstream/handle/10803/145065/Coll2013_ PhDthesis.pdf.

Coll, J.R., Jones, P.D., Aguilar, E. 2015. Expected changes in mean seasonal precipitation and temperature across the Iberian Peninsula for the 21st century. Idójárás 119 (1), 1-22.

Dai, A. 2012. Increasing drought under global warming in observations and models. Nature Climate Change. Doi: 10.1038/NCLIMATE1633.

Dai, A. 2011. Drought under global warming: A review. Climate Change 2, 45-65. Doi:10.1002/ wcc. 81 .

De Luís, M., González-Hidalgo, J.C., Longares, L.A., Stepánek, P. 2009. Seasonal precipitation trends in the Mediterranean Iberian Peninsula in second half of 20th century. International Journal of Climatology 29, 1312-1323.

Domínguez-Castro, F., Ribera, P., García-Herrera, R., Vaquero, J.M., Barriendos, M., Cuadrat, J.M., Moreno, J.M. 2012. Assessing extreme droughts in Spain during 1750-1850 from rogation ceremonies. Climate of the Past 8 (2), 705-722. Doi: 10.5194/cp-8-705-2012.

Gallego, M.C., Trigo, R.M., Vaquero, J.M., Brunet, M., García, J.A., Sigró, J., Valente, M.A. 2011. Trends in frequency indices of daily precipitation over the Iberian Peninsula during the last century. Journal of Geophysical Research-Atmosphere. Doi: 10.1029/2010JD014255, 2011.

Hargreaves, G.L., Samani, Z.A. 1985. Reference cop evapotranspiration from temperature. Applied Engineering and Agriculture 1, 96-99.

Hartmann, D.L., Klein Tank, A.M.G., Rusticucci, M., Alexander, L.V., Brönnimann, S., Charabi, Y., Dentener, F.J., Dlugokencky, E.J., Easterling, D.R., Kaplan, A., Soden, B.J., Thorne, P.W., Wild, M., Zhai, P.M. 2013. Observations: Atmosphere and Surface. In T.F. Stocker, D. Qin, G.K. Plattner, M. Tignor, S.K. Allen, J. Boschung, A. Nauels, Y. Xia, V. Bex and P.M. Midgley (eds.), Climate Change 2013: The Physical Science Basis. Contribution of Working Group I to the Fifth Assessment Report of the Intergovernmental Panel on Climate Change. Cambridge University Press, Cambridge, United Kingdom and New York.

Kallis, G. 2008. Droughts. Annual Review of Environmental Resources 33, 85-118.

Kendall, M.G. 1970. Rank Correlation Methods (4th ed). Griffin and Co. Ltd.

Kirtman, B., Power, S.B., Adedoyin, J.A., Boer, G.J., Bojariu, R., Camilloni, I., Doblas-Reyes, F.J., Fiore, A.M., Kimoto, M., Meehl, G.A., Prather, M., Sarr,, A., Schär, C., Sutton, R., van Oldenborgh, G.J., Vecchi, G., Wang, H.J. 2013. Near-term Climate Change: Projections and Predictability. In: T.F. Stocker, D. Qin, G.K. Plattner, M. Tignor, S.K. Allen, J. Boschung, A. Nauels, Y. Xia, V. Bex and P.M. Midgley (eds.), Climate Change 2013: The Physical Science Basis. Contribution of Working Group I to the Fifth Assessment Report of the Intergovernmental Panel on Climate Change. Cambridge University Press, Cambridge, United Kingdom and New York.

Lorenzo-Lacruz, J., Vicente-Serrano, S.M., López-Moreno, J.I., Morán-Tejeda, E., Zabalza, J. 2012. Recent trends in Iberian streamflows (1945-2005). Journal of Hydrology 414-415, 463-475.

March, H., Domènech, L., Saurí, D. 2013. Water conservation campaigns and citizen perceptions: the drought of 2007-2008 in the Metropolitan Area of Barcelona. Natural Hazards 65, 19511966. Doi: 10.1007/s11069-012-0456-2.

Mestre, O., Domonkos, P., Picard, F., Auer, I., Robin, S., Lebarbier, E., Böhm, R., Aguilar, E., Guijarro, J., Vertachnik, G., Klancar, M., Gubuisson, B., Stepanek, P. 2013. HOMER: a homogenization software - methods and applications. Quarterly Journal of the Hungarian Meteorological Service 117, 47-67. 
McKee, T.B.N., Doesken, J., Kleist, J. 1993. The relationship of drought frequency and duration to time scales. Eight Conference on applied climatology, American Meteorological Society, Anaheim, CA, pp. 179-184.

Pastor, J.J. 2008. The drought of 2007-2008 in Catalonia. Unpublished report. Catalan Water Agency, Barcelona.

Pauling, A., Luterbacher, J., Casty, C., Wanner, H. 2006. Five hundred years of gridded highresolution precipitation reconstructions over Europe and the connection to large-scale circulation. Climate Dynamics 26, 387-405. Doi: 10.1007/s00382-005-0090-8.

Prohom, M., Barriendos, M., Sanchez-Lorenzo, A. 2015. Reconstruction and homogenization of the longest instrumental precipitation series in the Iberian Peninsula (Barcelona, 17862014). International Journal of Climatology. Doi: 10.1002/joc.4537.

Prohom, M., Barriendos, M., Aguilar, E., Ripoll, R. 2012. Recuperación y análisis de la series de temperatura diaria de Barcelona, 1780-2011. In Cambio Climático. Extremos e impactos, Spanish association of Climatology, Series A, Vol. 8, pp. 207-217.

Rodríguez-Puebla, C., Nieto, S. 2010. Trends of precipitation over Iberian Peninsula and the North Atlantic Oscillation under climate change conditions. International Journal of Climatology 30, 1807-181.

Salomon, S., Qin, D., Manning, M., Chen, Z., Marquis, M., Averyt, K.B., Tignor, M., Miler, H.L. (eds.) 2007. The Physical Science Basis. Contribution of Working Group I to the Fourth Assessment Report of the International Panel on Climate Change Program, Cambridge University Press, Cambridge and New York, 996 pp.

Santos, J., Pulido-Calvo, I., Portela, M. 2010. Spatial and temporal variability of droughts in Portugal. Water Resources Research. Doi: 10.1029/2009WR008071.

Sheffield, J., Wood, E.F., Roderick, M.L. 2012. Little change in global drought over the past 60 years. Nature 491, 435-438. Doi:10.1038/nature11575.

Sigró, J., Brunet, M., Domonkos, P., Aguilar, E., Gilabert, A., Lister, D., Luna, Y., Mestre, A., Jones, P.D. 2015. Long-term temperature change over mainland Spain: an update to 2014 and reassessment of the Spanish Daily Adjusted Temperature Series (SDATS). Proceeding of the CLIMATE-ES Workshop, Tortosa, Spain. Available at: http://www.climaes2015.urv. cat/wp-content/uploads/2015/02/CLIMA2015_2_Javier-Sigro-Rodriguez.pdf.

Sousa, P., Trigo, R.M., Aizpurua, P., Nieto, R., Gimeno, L., García-Herrera, R. 2011. Trends and extremes of drought indices throughout the 20th century in the Mediterranean. Natural Hazards and Earth System Science 11, 33-51. Doi: 10.5194/nhess-11-33-2011.

Thornthwaite, C.W. 1948. An approach toward a rational classification of climate. Geographical Review 38, 55-94.

Trenberth, K.E., Dai, A., van der Schrier, G., Jones, P.D., Barichivich, J., Briffa, K.R., Sheffield, J. 2014. Global warming and changes in drought. Nature Climate Change 4, 17-22. Doi: 10.1038/nclimate2067.

Trenberth, K.E. 2007. Observations: Surface and Atmospheric Climate Change. In S. Solomon, D. Qin, M. Manning, Z. Chen, M. Marquis, K.B. Averyt, M. Tignor, H.L. Miller (eds.), Climate Change 2007: The Physical Science Basis. Contribution of Working Group I to the Fourth Assessment Report of the Intergovernmental Panel on Climate Change, Cambridge University Press, Cambridge, United Kingdom and New York.

van der Schrier, G., Barichivich, J., Jones, P.D., Briffa, K.R. 2013. A sc-PDSI-based global dataset of dry and wet spells for 1901-2009. Journal of Gephysical Research 118, 4025-4048. Doi: 10.1002/jgrd.50355.

van der Schrier, G., Jones, P.D., Briffa, K.R. 2011. The sensitivity of the PDSI to the Thorthwaite and Penman-Monteith parameterizations for potential evapotranspiration. Journal of Geophysical Research 116, D03106. Doi: 10.1029/2010JD015001. 
Venema, V.K.C, Mestre, O., Aguilar, E., Auer, I., Guijarro, J.A., Domonkos, P., Vertacnik, G., Szentimrey, T., Stepanek, P., Zahradnicek, P., Viarre, J., Müller-Westermeier, G., Lakatos, M., Williams, C.N., Menn, M.J., Lindau, R., Rasol, D., Rustemeier, E., Kolokythas, K., Marinova, T., Andresen, L., Acquaotta, F., Fratianni, S., Cheval, S., Klancar, M., Brunetti, M., Gruber, C., Prohom Duran, M., Likso, T., Esteban, P., Brandsma, T. 2012. Benchmarking homogenization algorithms for monthly data. Climate of the Past 8, 89-115. Doi: 10.5194/ cp-8-89-2012.

Vicente-Serrano, S.M., López-Moreno, J.I., Beguería, S., Lorenzo-Lacruz, J., Sánchez-Lorenzo, A., García-Ruiz, J.M., Azorin-Molina, C., Revuelto, J., Trigo, R., Coelho, F., Espejo, F. 2014a. Evidence of increasing drought severity caused by temperature rise in southern Europe. Environmental Research Letters 9, 044001. Doi: 10.1088/1748-9326/9/4/044001.

Vicente-Serrano, S.M., Chura, O., López-Moreno, J.I., Azorin-Molina, C., Sánchez-Lorenzo, A., Aguilar, E., Moran-Tejeda, E., Trujillo, F., Martínez, R., Nieto, J.J. 2014b. Spatial-temporal variability of droughts in Bolivia: 1955-2012. International Journal of Climatology. Doi: 10.1002/joc. 4190 .

Vicente-Serrano, S.M., Beguería, S., López-Moreno, J.I. 2011. Comment on "Characteristics and trends in various forms of the Palmer Drought Severity Index (PDSI) during 1900-2008" by Aiguo Dai. Journal of Geophysical Research 116, D19112. Doi: 10.1029/2011JD016410.

Vicente-Serrano, S.M., Beguería, S., López-Moreno, J.I. 2010a. A multi-scalar drought index sensitive to global warming: the standardized precipitation evapotranspiration index. Journal of Climate 23, 1696-1718. Doi: 10.1175/2009JCLI2909.1.

Wang, X.L., Swail, V.R. 2001. Changes of extreme wave height in Northern Hemisphere oceans and related atmospheric circulation regimes. Journal of Climate 14, 12-45. 